\title{
Evaluation of environment friendly micro-ionized litchi leaves powder (LLP) as a fluid loss control agent in water-based drilling fluid
}

\author{
Ved Prakash $^{1,2}$ D $\cdot$ Neetu Sharma ${ }^{1} \cdot$ Munmun Bhattacharya ${ }^{2} \cdot$ Ashok Raina $^{2} \cdot$ Man Mohan Gusain $^{2} \cdot$ Kiran Sharma $^{3}$
}

Received: 13 September 2020 / Accepted: 12 March 2021 / Published online: 24 March 2021

(c) The Author(s) 2021

\begin{abstract}
This work investigates the efficacy of a biodegradable natural product, litchi leaves powder (LLP) as a filtration loss control agent in the water-based drilling fluid formulations. In order to evaluate the potential of litchi leaves powder (LLP), a strict protocol of experimentations according to API (American Petroleum Institute) standard has been followed. The experimental outcome showed that before hot rolling and after hot rolling of mud samples at $100{ }^{\circ} \mathrm{C}$ it was observed that 3-5\% Concentration of LLP significantly increased the rheological parameters such as PV, YP and gelation of drilling fluid as compared to reference mud. Also, LLP reformed the filtration loss control characterization, suggesting a better biodegradable fluid loss reducing agent. After hot rolling at $100{ }^{\circ} \mathrm{C}$ for $18 \mathrm{~h}$, the water-based drilling fluid with LLP as an additive showed a marked reduction in filtration control property as compared to reference Mud (RM). Experimental results concluded that 5\% concentration of LLP significantly reduced the filtration loss of drilling fluid by $70.6 \%$ as compared to reference mud under the influence of 100 psi pressure. However, the conventional fluid loss additive CMC (LVG) reduced the filtration loss by maximum $67.5 \%$ as compared to reference mud. Therefore, LLP can be used as an alternative to CMC (LVG) in water-based drilling fluid with a maximum subsurface temperature of $100{ }^{\circ} \mathrm{C}$.
\end{abstract}

Keywords Environment friendly additive $\cdot$ Drilling fluid $\cdot$ Litchi leaves powder $($ LLP) $\cdot$ CMC $\cdot$ Filtration loss

\begin{tabular}{ll}
\multicolumn{2}{l}{ Abbreviations } \\
API & American Petroleum Institute \\
AV & Apparent Viscosity \\
PV & Plastic Viscosity \\
YP & Yield Point \\
LLP & Litchi Leaves Powder \\
RM & Reference Mud \\
CMC (LVG) & Carboxymethyl Cellulose (Low Viscous \\
& Grade) \\
${ }^{\circ}$ C & Degree Celsius \\
psi & Pounds square inch \\
LTLP & Low Temperature-Low Pressure \\
lb/bbl & Pounds per barrel
\end{tabular}

Ved Prakash

vedprakashdhyani28@gmail.com

1 Department of Chemistry, Graphic Era, Deemed to be University Dehradun, Dehradun, Uttarakhand, India

2 Department of Drilling Fluid Engineering (R\&D), Institute of Drilling Technology (IDT), Oil and Natural Gas Corporation Limited (ONGC), Dehradun, Uttarakhand, India

3 Department of Physics, Graphic Era Deemed to be University Dehradun, Dehradun, Uttarakhand, India

$\begin{array}{ll}\text { lb/gal } & \text { Pounds per gallon } \\ \text { AHR } & \text { After Hot rolling } \\ \text { BHR } & \text { Before Hot rolling } \\ \text { FTIR } & \text { Fourier transform infrared }\end{array}$

\section{Introduction}

A drilling fluid is designed in order to cater various functions during drilling and its high efficiency is rated high, if the various chemical additives and polymers are mixed to the base fluid to fulfil the required parameters of the drilling fluid, such as density, shale stabilization, filtration loss control, alkalinity, lubricity, etc. (Gray et al. 1980; Okorie et al. 2009). As per environmental aspect, oil-based drilling fluids are more toxic than water-based drilling fluids. So keeping in view these facts and the environmental compatibility, it has initiated an interest among users to use water-based drilling fluid as compared to the oil-based drilling fluid (Amanullah 2007). Corncob and sugar cane additives have been used as viscosifying agent. The results of this study showed that when the concentration of sugarcane and corncob were increased from 6 to 10 parts per billion (ppb), there was an 
advancement in PV, but YP and gel strength were reduced (Iranwan et al. 2009). 20 parts per billion (ppb) concentrations of rice husks reduced the filtration loss in water-based mud by $65 \%$. But it was observed that a higher concentration of rice husk gave unwanted effect on the plastic viscosity (Okon et al. 2014). Banana peel provided alkalinity to the drilling fluid system (Iheagwara et al. 2015). Similarly, the banana peel ash (BPA) was used as a substitute for $\mathrm{NaOH}$ in water-based mud. The experimental results showed that banana peels ash (BPA) has a tendency to increase the $\mathrm{pH}$ of drilling mud and thereby mitigated the corrosion problem. On comparing BPA with $\mathrm{NaOH}$, it was observed that there was better improvement in $\mathrm{pH}$ ranging from 12 and $14 \%$ in the case of banana peels (Adebowale and Raji 2015).

Other natural additives such as extracted cellulose from corn cob (Nmegbu and Bekee 2014), extracted cashew and mango leaves (Omotioma et al. 2014), and extracted potato starch from potato tubers (Nyeche et al. 2015), etc. have been used as filtration loss control and rheological properties modifiers in water-based drilling fluids. Potato peels powder (PPP) is an environmental friendly additive to be used as thinner, $\mathrm{pH}$ reducer, and fluid loss controlling agent (AlHameedi and Husam 2019). However, another study showed the use of mandarin peels powder (MPP) as a filtration loss control additive to substitute the conventional chemicals used in water-based drilling fluid (Al-Hameedi and Alkinani 2019). In our previous study, Stem peels powder of Grewia optiva fibre (particle size $250 \mu \mathrm{m}$ ) has been used as cost effective and environment friendly non-invasive fluid additive in water-based fluid to prevent the invasion of external fluid into the reservoir section (Prakash et al. 2020).

In this study, litchi leaves powder (LLP) has been investigated as an environment friendly filtration loss control additive in the water-based drilling fluid. Litchi chinensis is an evergreen tree which belongs to the spindaceae family. Litchi trees are mainly found in China, India, Thailand, Vietnam, Australia, Israel and the South-Eastern United States. Extensive laboratory works have been conducted where LLP was tested at different concentrations w.r.t. reference mud. The experimental outcomes suggested that this natural product, i.e. LLP is an environmental friendly, cost effective, drilling fluid additive. The performance of the drilling fluid was found to be at par excellence with litchi leaves powder (LLP) when it was compared with a conventional fluid loss additive CMC (Carboxymethyl Cellulose).

\section{Basis of choice of litchi leaves for the study}

Biomolecules content Litchi leaves have greater content of carbohydrate, i.e. $72.547 \%$. Beside this, it also contained $31.041 \%$ crude fibre, $12.751 \%$ crude protein, $2.022 \%$ crude fat and $2.04 \%$ of total nitrogen (Shukla et al. 2014).

Cost analysis The cost of conventional fluid loss control additives, e.g. CMC (LVG) and Polyanionic cellulose are $4.96 \mathrm{USD}$ per $\mathrm{Kg}$ and $6.0 \mathrm{USD} / \mathrm{Kg}$, respectively (Okoro et al. 2018). However, LLP is a natural waste and easily available from the natural resources in a huge quantity. Therefore, LLP is more cost effective than CMC (LVG) and PAC (LVG).

\section{Materials and methods}

\section{Preparation of micro-ionized litchi leaves powder (LLP)}

The sample [as shown in Fig. 1a] was cleaned manually to get rid of unwanted foreign materials. Then, it was dried in an oven at $70-75^{\circ} \mathrm{C}$ for about $\sim 4 \mathrm{~h}$. After drying, it was then again cleaned manually and chopped into small pieces [as shown in Fig. 1b]. Finally, the sample was ground into very fine particles with the help of good quality Grinder Machine [shown in Fig. 1d].

Sieve analysis test was conducted to determine the particle size of litchi leaves powder (LLP). The fine LLP was sieved through $125 \mu \mathrm{m}(\mu \mathrm{m})$ (120 US Mesh sieve) to obtain micro-sized fine particle [shown in Fig. 1c]. The reason for using $125 \mu \mathrm{m}$ particle size as because smaller the size of

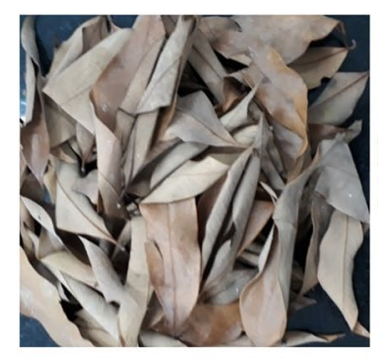

(a)

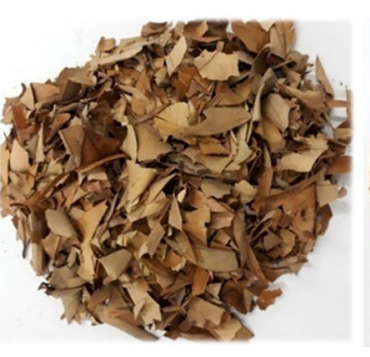

(b)

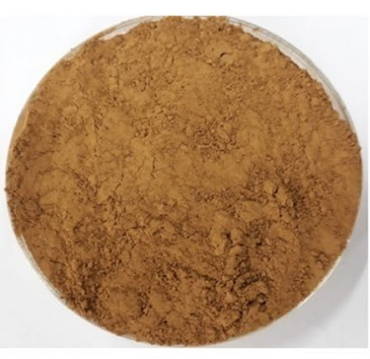

(c)

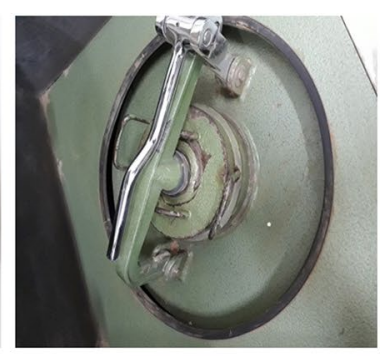

(d)

Fig. 1 a Collected raw Litchi leaves, b Small Pieces of Litchi Leaves, c The Litchi Leaves Powder (125 $\mu$ m), d Grinder

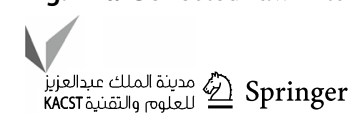


additive gives better filtration loss control ability of the drilling mud (Ghazali et al. 2014; Perlmutter 2005).

\section{Experimental procedures}

\section{$\mathrm{pH}$}

$5 \%(\mathrm{w} / \mathrm{v})$ sample was taken in deionized/distilled water and stirred on magnetic stirrer for $10 \mathrm{~min}$, then determined the $\mathrm{pH}$ of the solution at $24 \pm 2{ }^{\circ} \mathrm{C}$ by using a calibrated $\mathrm{pH}$ meter. The result is shown in Table 1.

\section{Moisture content}

$10 \mathrm{~g}$ of dried sample was taken in a pre-weighed bottle with lid. Removed the lid and placed both the lid and bottle separately in an air oven at $105 \pm 2{ }^{\circ} \mathrm{C}$ temperature. Keeping for $5 \mathrm{~h}$ in air oven, when the sample was dried completely, placed the lid on the bottle inside the oven and then cooled in desiccator before weighing. Removed and replaced the lid quickly to equalize the pressure inside the desiccator. Repeated the process till constant weight was obtained (Chiachung et al. 2003; Ayurveda formulary of India 2000). The result is shown in Table 1.

\section{Calculation:}

Table1 Properties of Litchi Leaves powder (LLP)

\begin{tabular}{lll}
\hline S. No & Properties & Observation/values \\
\hline 1 & Physical state & Powder \\
2 & Colour & Yellow-Greenish \\
3 & $\mathrm{pH}$ of $5 \%$ sample in Dis- & 6.5 \\
& tilled water at $24 \pm 2{ }^{\circ} \mathrm{C}$ & \\
4 & Moisture content at & 6 \\
& $105 \pm 2{ }^{\circ} \mathrm{C}$, per cent by & \\
& mass & \\
\hline
\end{tabular}

Moisture content $\%(w / w)=\frac{(W 2-W 1)}{W 1} \times 100$

where $W 1=$ Weight of bottle with lid + Sample, $W 2=$ Weight of bottle with lid + Dried Sample.

\section{Mud sample preparation}

A freshwater bentonite-based drilling fluid was prepared as per API (American Petroleum Institute) standards. The standard procedure involves the addition of $25 \mathrm{gms}$ of bentonite powder and $0.7 \mathrm{gm}$ of caustic soda $(\mathrm{NaOH})$ in $350 \mathrm{ml}$ of fresh water. The mixture was kept for maturation for $24 \mathrm{~h}$. Since freshwater bentonite-based drilling fluid is a colloidal system and the maximum hydration \& yield of bentonite is $\mathrm{pH}$ based, caustic soda, as an important ingredient added for maintaining proper alkalinity, $\mathrm{pH}$ to be maintained at maximum 10.5 .

The drilling fluid prepared with bentonite and caustic Soda $(\mathrm{NaOH})$, here it was referred as Reference Mud. The rheological and fluid loss property of the reference mud was measured, and the results are tabulated in Table 2.

The mud samples were grouped into two sets, nomenclature as Set.1 \& Set-2. In Set-1, 1\%, 2\%, 3\%, 4\% \& 5\% of $125 \mu \mathrm{m}$ sized litchi leaves powder (LLP) were added to reference mud, respectively, and mixed thoroughly for $10 \mathrm{~min}$ in order to get a homogeneous mixture of bentonite mud with litchi leaves powder. Consequently, the rheological properties of each sample including low temperature-low pressure (LTLP) filtration test were carried out on each set of samples and the results acquired are presented in Table 2 .

Set-2, an another set of samples $0.6 \%, 0.8 \%, 1.0 \%, 1.2 \%$ and $1.4 \%$ of CMC (LVG) was added to reference mud, respectively, and mixed by stirring the mixture for $10 \mathrm{~min}$ to obtain a homogeneous mixture. The, the rheological properties, fluid loss volume and mud cake thickness of the
Table 2 The results of adding various concentrations of LLP on the properties of Reference Mud, Before Hot Rolling (BHR)

\begin{tabular}{|c|c|c|c|c|c|c|c|}
\hline \multirow[t]{2}{*}{ S.N } & \multirow[t]{2}{*}{ Properties } & \multicolumn{6}{|l|}{ Values } \\
\hline & & $\begin{array}{l}\text { Reference } \\
\text { Mud (RM) }\end{array}$ & $1 \%$ LLP & $2 \%$ LLP & $3 \%$ LLP & $4 \%$ LLP & $5 \%$ LLP \\
\hline 1 & Mud weight (ppg) & 8.6 & 8.6 & 8.55 & 8.5 & 8.4 & 8.35 \\
\hline 2 & $\mathrm{pH}$ & 10.5 & 10.4 & 10.4 & 10.2 & 10.1 & 10.0 \\
\hline 3 & PV (cp) & 7.0 & 10 & 12 & 14 & 18 & 20 \\
\hline 4 & YP (Ib/100ft2) & 12 & 13 & 15 & 18 & 20 & 25 \\
\hline 5 & Gel 0 (Ib/100ft2) & 8 & 10 & 12 & 14 & 16 & 18 \\
\hline 6 & Gel 10 (Ib/100ft2) & 16 & 17 & 19 & 22 & 24 & 26 \\
\hline 7 & Mud temperature $\left({ }^{\circ} \mathrm{F}\right)$ & 75 & 75 & 75 & 75 & 75 & 75 \\
\hline 8 & 7.5 min filtrate $(\mathrm{cc})$ & 13 & 8.0 & 6.2 & 4.7 & 4.3 & 3.4 \\
\hline 9 & 30 min filtrate $(\mathrm{cc})$ & 27 & 15 & 12.3 & 9.5 & 8.6 & 6.8 \\
\hline 10 & Filter cake thickness (mm) & 3 & 2.8 & 2.4 & 1.8 & 1.6 & 1.4 \\
\hline 11 & Mud cake temperature $\left({ }^{\circ} \mathrm{F}\right)$ & 77 & 77 & 77 & 77 & 77 & 77 \\
\hline
\end{tabular}


Set- 2 were similarly measured and the data are presented in Table 3.

After evaluating the above sets of samples at low pressure-low temperature, the reference mud and Set- 1 and Set- 2 mud samples were now put in ageing cells and hot rolled at $100{ }^{\circ} \mathrm{C}$ for $18 \mathrm{~h}$. Hot rolling of mud samples is necessary because during the drilling the bottom hole temperature of well is increased with increasing the well depth. Therefore, temperature distribution under circulation and shut in conditions is necessary to maintain the viscosity, fluid loss, $\mathrm{pH}$ shale inhibition, etc. properties of the drilling fluid and prevent the invasion of annulus fluid fluxed into formation during loss circulation problem in oil and gas geothermal wells (Fomin et al. 2003).

The rheological properties and low temperature-low pressure filtration test of all these hot rolled samples were then carried out and the results are presented in Tables 4 and 5, respectively.
Filtration test (low pressure, low temperature test)

API specified filter press is used to determine the filtration properties of the drilling fluid. A Whatman 50 filter paper was placed in the API cell and then it was filled by the mud. Then, 100 psi pressure was applied to the API cell at room temperature. Then, the volume of filtrate was measured after 7.5 and 30 min (American Petroleum institute 2003).

\section{Filter cake characteristic measurements}

The qualitative measurements of the filter cake like thickness, thinness, firm, rubbery, sticky, smooth, etc. were determined as per API Standard. The cake characterizations such as slickness and texture were determined subjectively by physical examination, whereas the thickness of cake was measured quantitatively by using a scale and reported in

Table 3 The results of adding various concentration of CMC (LVG) on the properties of Reference Mud, Before Hot Rolling (BHR)

\begin{tabular}{|c|c|c|c|c|c|c|c|}
\hline \multirow[t]{2}{*}{ S. no } & \multirow[t]{2}{*}{ Properties } & \multicolumn{6}{|l|}{ Values } \\
\hline & & $\begin{array}{l}\text { Reference Mud } \\
\text { (RM) }\end{array}$ & $0.6 \% \mathrm{CMC}$ & $0.8 \% \mathrm{CMC}$ & $1.0 \% \mathrm{CMC}$ & $1.2 \% \mathrm{CMC}$ & $1.4 \% \mathrm{CMC}$ \\
\hline 1 & Mud weight (ppg) & 8.6 & 8.6 & 8.62 & 8.63 & 8.64 & 8.64 \\
\hline 2 & $\mathrm{pH}$ & 10.5 & 10.2 & 10.1 & 10 & 9.9 & 9.8 \\
\hline 3 & PV (cp) & 7.0 & 16 & 20 & 24 & 28 & 32 \\
\hline 4 & YP (Ib/100ft2) & 12 & 17 & 39 & 41 & 43 & 46 \\
\hline 5 & Gel 0 (Ib/100ft2) & 8 & 18 & 22 & 26 & 32 & 34 \\
\hline 6 & Gel 10 (Ib/100ft2) & 16 & 26 & 30 & 38 & 42 & 48 \\
\hline 7 & Mud temperature $\left({ }^{\circ} \mathrm{F}\right)$ & 75 & 75 & 75 & 75 & 75 & 75 \\
\hline 8 & 7.5 min filtrate (cc) & 13 & 3.5 & 3.0 & 2.7 & 2.6 & 2.5 \\
\hline 9 & 30 min filtrate (cc) & 27 & 11 & 10.2 & 9.3 & 8.1 & 7.6 \\
\hline 10 & Filter cake thickness $(\mathrm{mm})$ & 3 & 2.4 & 2.2 & 2.1 & 1.8 & 1.6 \\
\hline 11 & Mud cake temperature $\left({ }^{\circ} \mathrm{F}\right)$ & 77 & 77 & 77 & 77 & 77 & 77 \\
\hline
\end{tabular}

Table 4 The results of adding various concentration of LLP on the properties of Reference Mud, After Hot Rolling (AHR) at $100{ }^{\circ} \mathrm{C}$ for $18 \mathrm{~h}$

\begin{tabular}{|c|c|c|c|c|c|c|c|}
\hline \multirow[t]{2}{*}{ S. no } & \multirow[t]{2}{*}{ Properties } & \multicolumn{6}{|l|}{ Values } \\
\hline & & $\begin{array}{l}\text { Reference } \\
\text { Mud (RM) }\end{array}$ & $1 \%$ LLP & $2 \%$ LLP & $3 \%$ LLP & $4 \%$ LLP & $5 \%$ LLP \\
\hline 1 & Mud weight (ppg) & 8.6 & 8.6 & 8.62 & 8.64 & 8.65 & 8.68 \\
\hline 2 & $\mathrm{pH}$ & 10 & 9.8 & 9.7 & 9.6 & 9.4 & 9.2 \\
\hline 3 & PV (cp) & 06 & 07 & 10 & 12 & 14 & 16 \\
\hline 4 & $\mathrm{YP}(\mathrm{Ib} / 100 \mathrm{ft} 2)$ & 07 & 08 & 09 & 14 & 15 & 18 \\
\hline 5 & Gel 0 (Ib/100ft2) & 06 & 08 & 13 & 16 & 18 & 19 \\
\hline 6 & Gel 10 (Ib/100ft2) & 12 & 14 & 18 & 20 & 22 & 25 \\
\hline 7 & Mud temperature $\left({ }^{\circ} \mathrm{F}\right)$ & 75 & 75 & 75 & 75 & 75 & 75 \\
\hline 8 & 7.5 min filtrate (cc) & 16 & 8.6 & 7.6 & 6.6 & 5.6 & 4.7 \\
\hline 9 & 30 min filtrate (cc) & 32 & 17 & 15.3 & 13.2 & 11.2 & 9.4 \\
\hline 10 & Filter cake thickness (mm) & 3.5 & 3.1 & 2.8 & 2.5 & 2.2 & 1.8 \\
\hline 11 & Mud cake temperature $\left({ }^{\circ} \mathrm{F}\right)$ & 77 & 77 & 77 & 77 & 77 & 77 \\
\hline
\end{tabular}


Table 5 The results of adding various concentration of CMC (LVG) on the properties of Reference Mud, After Hot Rolling (AHR) at $100{ }^{\circ} \mathrm{C}$ for $18 \mathrm{~h}$

\begin{tabular}{|c|c|c|c|c|c|c|c|}
\hline \multirow[t]{2}{*}{ S. no } & \multirow[t]{2}{*}{ Properties } & \multicolumn{6}{|l|}{ Values } \\
\hline & & $\begin{array}{l}\text { Reference Mud } \\
(\mathrm{RM})\end{array}$ & $0.6 \% \mathrm{CMC}$ & $0.8 \% \mathrm{CMC}$ & $1 \% \mathrm{CMC}$ & $1.2 \% \mathrm{CMC}$ & $1.4 \% \mathrm{CMC}$ \\
\hline 1 & Mud weight (ppg) & 8.6 & 8.63 & 8.64 & 8.66 & 8.68 & 8.68 \\
\hline 2 & $\mathrm{pH}$ & 10 & 9.9 & 9.8 & 9.6 & 9.3 & 9.0 \\
\hline 3 & PV (cp) & 06 & 16 & 16 & 24 & 26 & 41 \\
\hline 4 & YP (Ib/100ft2) & 07 & 20 & 28 & 35 & 38 & 42 \\
\hline 5 & Gel 0 (Ib/100ft2) & 06 & 14 & 18 & 20 & 24 & 28 \\
\hline 6 & Gel 10 (Ib/100ft2) & 12 & 24 & 28 & 32 & 38 & 42 \\
\hline 7 & Mud temperature $\left({ }^{\circ} \mathrm{F}\right)$ & 75 & 77 & 77 & 77 & 77 & 77 \\
\hline 8 & 7.5 min filtrate $(\mathrm{cc})$ & 16 & 7.0 & 6.3 & 6.0 & 5.7 & 5.3 \\
\hline 9 & 30 min filtrate $(\mathrm{cc})$ & 32 & 14 & 12.7 & 12.0 & 11.5 & 10.4 \\
\hline 10 & Filter cake thickness $(\mathrm{mm})$ & 3.5 & 2.9 & 2.7 & 2.5 & 2.3 & 2.1 \\
\hline 11 & Mud cake temperature $\left({ }^{\circ} \mathrm{F}\right)$ & 77 & 77 & 77 & 77 & 77 & 77 \\
\hline
\end{tabular}

millimetres. (Okorie et al. 2019; Amanullah and Tan 2001) (Fig. 2).

\section{Permeability of the filter cake}

The permeability of the filter cake is calculated from the relationship between the measured filtrate loss volume and time (shown in Eq. 1) (Elkatatny et al. 2012; Engelhardt 1954).

$K=\left(Q_{t} \times l_{t} \times \mu\right) \times \frac{1}{2 P \times F \times t}$

where $K=$ The permeability of the filter cake $(k), Q_{t}=$ volume of the filtrate in $\mathrm{cm}^{3}$ after time $t, l_{t}=$ Filter cake thickness in $\mathrm{cm}, \mu=$ viscosity of the filtrate in centipoise, $P=$ The filtration pressure in Atmosphere, $F=$ Effective filter surface in $\mathrm{cm}^{2}, t=$ time in seconds.

\section{Results and discussions}

\section{FTIR analysis of LLP}

Fourier transform infrared spectroscopy with $500-4000 \mathrm{~cm}^{-1}$ range was used to analyse the characterization of the LLP. Figure 3 shows the FTIR spectrum of raw LLP. The band at $3420 \mathrm{~cm}^{-1}$ assigned to the $\mathrm{O}-\mathrm{H}$ and $\mathrm{N}-\mathrm{H}$ stretching group through hydrogen bonding, indicating the presence of the hydroxyl and amino functional groups. The absorption band at $2925 \mathrm{~cm}^{-1}$ and $2853 \mathrm{~cm}^{-1}$ is attributed to the Aliphatic $\mathrm{C}-\mathrm{H}$ stretching vibration, showing the alkyl group $\left(-\mathrm{CH}_{2}-\right)$. The peak at $1733 \mathrm{~cm}^{-1}$ assigned to $\mathrm{C}=\mathrm{O}$ stretching vibration, showing the presence of a carbonyl group (ketone or aldehyde). The band at $1624 \mathrm{~cm}^{-1}$ is assigned to the, $\mathrm{N}-\mathrm{H}$ bending vibration, indicating the presence of amino $\left(-\mathrm{NH}_{2}\right)$ group. The absorption band at $1515 \mathrm{~cm}^{-1}$



(a)

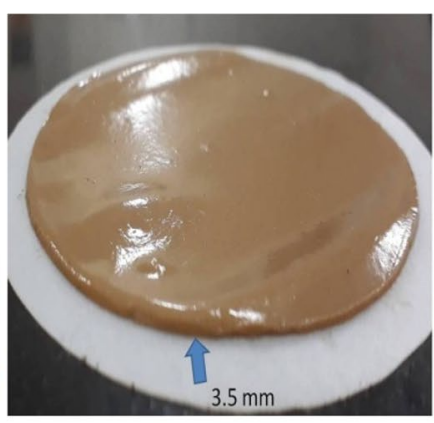

(b)

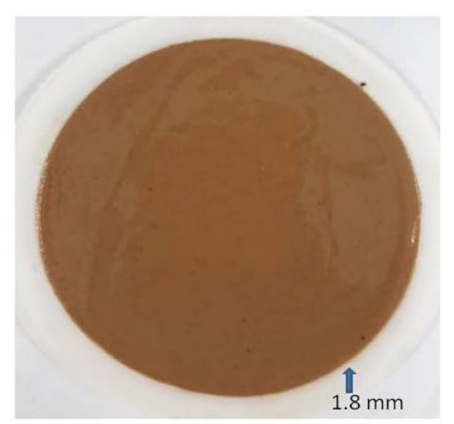

(c)

Fig. 2 a API LTLP filter press used for the experiment, b filter cake thickness (3.5 mm) of Base Mud after hot rolling, c filter cake thickness $(1.8 \mathrm{~mm})$ of $5 \%$ LLP Mud after hot rolling 


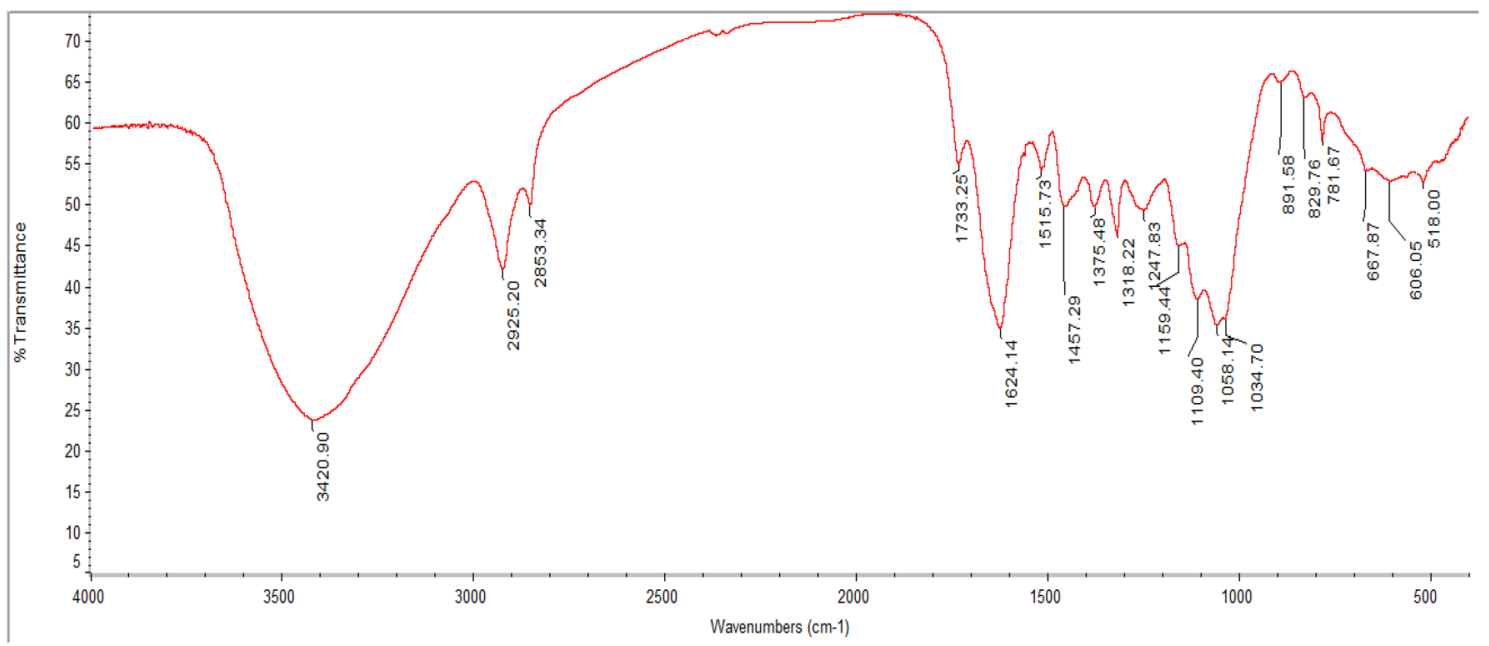

Fig. 3 FTIR Spectrum of LLP

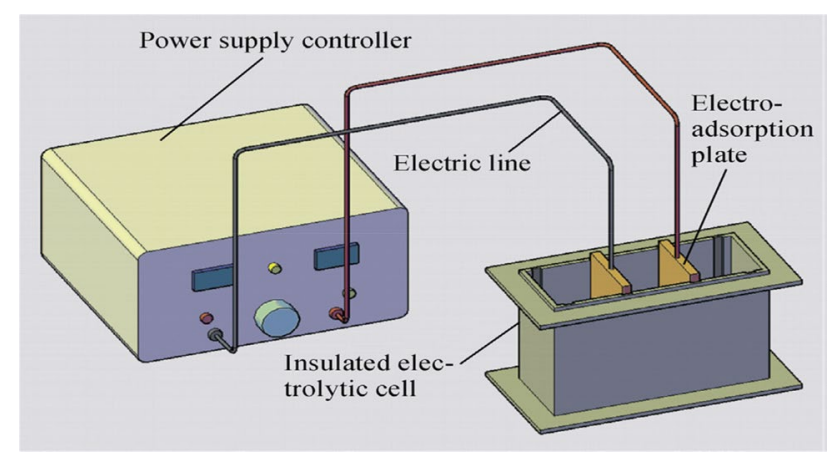

Fig. 4 Schematic diagram of electrosorption experimental device (Xie et al. 2018)

corresponds to $\mathrm{N}-\mathrm{H}$ bend (secondary amine). The peak at $1457 \mathrm{~cm}^{-1}$ corresponds to $\mathrm{C}-\mathrm{H}$ bending vibration while the peak at $1375 \mathrm{~cm}^{-1}$ correspond to $\mathrm{C}=0$ symmetrical stretching vibration, indicating the presence of carboxylic group. The absorption peaks from 1318 to $1058 \mathrm{~cm}^{-1}$ correspond to $\mathrm{C}-\mathrm{O}$ stretching, $\mathrm{C}-\mathrm{N}$ stretching and $\mathrm{C}-\mathrm{C}$ bending vibration. The absorption peaks from 891 to $518 \mathrm{~cm}^{-1}$ represent to $\mathrm{C}-\mathrm{X}$ stretching vibration $(\mathrm{X}=\mathrm{Cl}, \mathrm{Br}, \mathrm{I})$, showing the presence of halide group.

\section{Electrosorption experiment}

Electrosorption device is used for conducting electrosorption experiment. This device consists of three parts: a power supplier controller, electrolytic cell and a plug in electrosorption plate, as shown in Fig. 4.

Approx. 2L quantity of drilling fluid (containing 5\% LLP in fresh water) was put in the electrolytic cell and inserted electrosorption plates into the corresponding slot. The area of the immersed plate in the drilling fluid is 92.4 $\mathrm{cm}^{2}(12 \mathrm{~cm}$ (length) $\times 7.7 \mathrm{~cm}$ (width). When target voltage of experiment is achieved, started the adsorption time of sample. After the completion of experimental time, the adsorbed solid particles of sample at electrosorption plates were scraped into a beaker and put it in an oven for drying. When sample was dried completely, the amount of solid particles adsorbed during the whole experiment was calculated by the difference in the initial and final weight of the sample (Xie et al. 2018). Experimental outcomes represented in Fig. 5a illustrated that with increasing the electrosorption voltage from 10 to $36 \mathrm{~V}$, increase the adsorbed mass of solid particle from 1 to $2.4 \mathrm{gm}$, respectively, on the surface of electrosorption plates. Similarly, experimental results shown in Fig. 5b revealed that the mass of solid particles adsorbed is directly proportional to the adsorption time. The mass of solid particles adsorbed were increases from 1 to $6.5 \mathrm{gm}$ with increasing the adsorption time from 3 to $30 \mathrm{~min}$, respectively.

\section{Mud samples analysis}

The data generated by experimental evaluation of this ecofriendly additive (litchi leaves powder) reflects the property of fluid loss control. Apart from fluid loss reduction, its effect on mud weight (MW), plastic viscosity (PV), yield point (YP), gel strength and other physical as well as chemical properties were also studied. An account of the experimental results discussing comprehensively each property at different level of concentration of LLP was also carried out against the reference mud sample. 


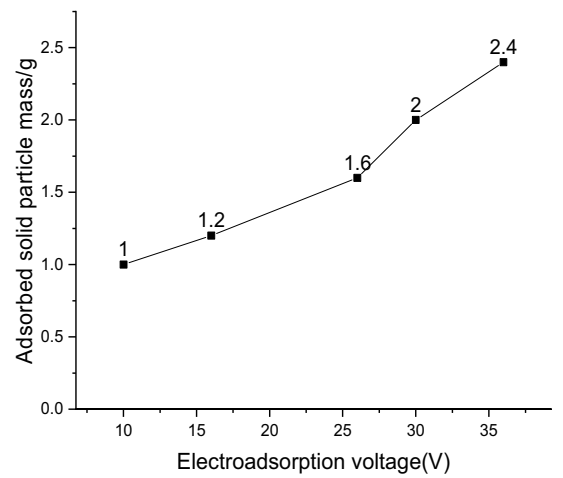

(a)

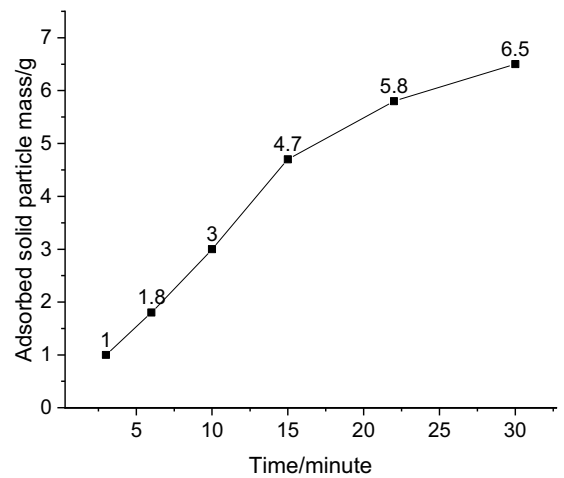

(b)

Fig. 5 a Effect of electrosorption voltage on the adsorbed solid particle mass. b Effect of electrosorption time on the adsorbed solid particle mass

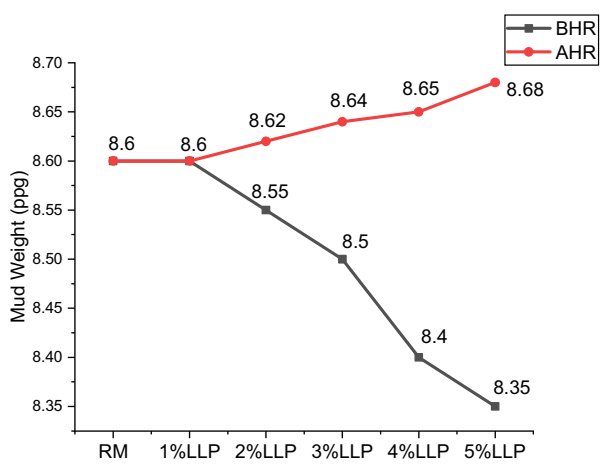

Fig. 6 Effect of different dosages of LLP on mud weight of drilling fluid samples

\section{Effect of LLP on the specific gravity of drilling fluid}

The experimental data represented in Tables 2 and 4 reveal that even after the sample was hot rolled at $100{ }^{\circ} \mathrm{C}$, this green additive had no impact on specific gravity of drilling fluid. The specific gravity of samples invariably showed very negligible changes in the physical properties of mud at any concentration ranging from 1 to of $5 \%$ with respect to reference mud sample. This indicated that LLP is a light natural product with low specific gravity. As evident from the data, Fig. 6 shows that the addition of $1 \%, 2 \%, 3 \%, 4 \%$ and $5 \%$ concentrations of the LLP to reference mud resulted in the increasing trend of specific gravity varying from 0.23 to $0.58 \%$. At low range of temperature, before hot rolling, it was observed that the specific gravity of mud decreased with increasing the concentration of LLP due to foaming phenomenon. The foaming is a physical surface phenomena which is removed by adding suitable defoaming agents.

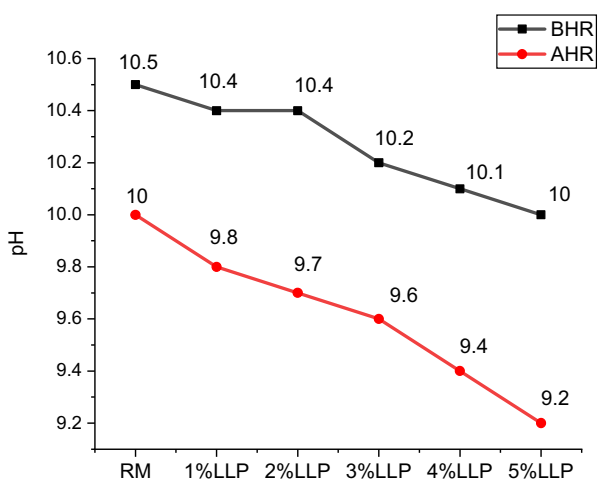

Fig. 7 Effect of LLP on $\mathrm{pH}$

\section{Effect of LLP on the pH of drilling fluid}

All aqueous-based drilling fluid systems are colloidal in nature and stable in alkaline environment. The befitting range of alkalinity encompassing various types of inhibitive drilling fluids is stable in the alkaline range from $\mathrm{pH} 9$ to 10.5 The alkalinity of the system also inhibits the corrosion characteristic of drilling fluid on the drilling equipment's. $\mathrm{pH}$ less than 7 represent the acidic medium and $\mathrm{pH}$ more than 7 represent the basic medium, whereas neutral solution represent the $\mathrm{pH}$ equal to 7 (MI-Drilling fluids 2000).

Experimental data set showed that after hot rolling of the drilling fluid sample for $18 \mathrm{~h}$ at $100{ }^{\circ} \mathrm{C}$, It was found that $\mathrm{pH}$ of mud has been reduced by $2-8 \%$ with varied concentration of LLP from 1 to 5\%, respectively (as shown in Fig. 7). However, $\mathrm{pH}$ of mud has been reduced by $1-10 \%$ with varied concentration of $\mathrm{CMC}(\mathrm{LVG})$ from 0.6 to $1.4 \%$, respectively, as compared to reference mud. 


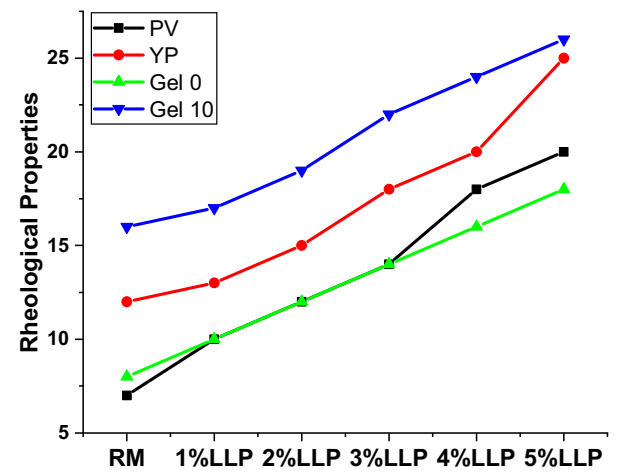

Fig. 8 Effect of LLP on the Rheological Properties of Drilling Fluid before hot rolling (BHR)

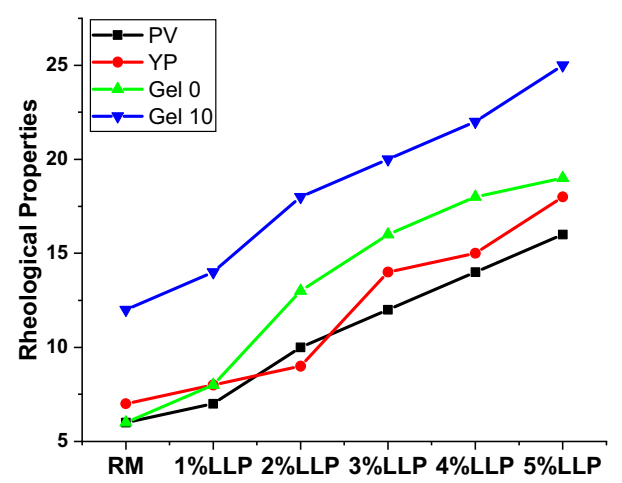

Fig. 9 Effect of LLP on the Rheological Properties after hot rolling at $100{ }^{\circ} \mathrm{C}(\mathrm{AHR})$

\section{Effect of LLP on the rheological properties of drilling fluids}

\section{Plastic viscosity (PV)}

Plastic viscosity of the drilling mud should be less as possible. PV indicates solid-solid and solid to liquid interaction. An enhancement of PV reduced the YP and decreased the hole cleaning capacity of drilling mud (Baker 2006). The experimental data represented in Figs. 8 and 9 show that $1-2 \%$ concentration of LLP had little effect on plastic viscosity w.r.t reference mud. However, 3-5\% concentration of LLP significantly increased the PV as compared to reference sample, due to frictional forces that may have increased due to the addition of LLP additive. Hence, to control the enhancement of PV, optimization is required. This optimization of LLP addition is based on section, size, depth of the formation drilled and also on the lithology of formation. It was also observed that the enhancement of PV with the various concentrations of LLP was very less as compared to that of CMC (LVG) which makes LLP a better additive than CMC because low PV indicates that the formulated drilling fluid has a good capability for smooth drilling operations without any complications.

\section{Yield point (YP)}

The experimental results represented in Figs. 8 and 9 show that after the addition of this natural product YP of drilling fluid was increased as compared to YP of reference mud. Although there was little effect on the YP with increasing concentration of LLP from 1 to $2 \%$, but as concentration increased from 3 to $5 \%$ there was an exponential enhancement in YP by twice to thrice as compared to reference mud. The YP of reference mud after hot rolling was $7 \mathrm{cP}$. However, the $\mathrm{YP}$ of $3 \%, 4 \%$ and $5 \%$ LLP mud were increased to $14 \mathrm{cP}, 15 \mathrm{cP}$ and $18 \mathrm{cP}$, respectively. This enhancement in YP indicates that LLP increased the magnitude of attractive forces among the particles of drilling fluid, which would be supported in the lifting of drill cuttings from the bottom hole to the surface.

\section{Gel strength}

Gelation/Gel strength of any drilling fluid is a thixotropic property that helps the system to hold suspended drill cutting during the static condition. Gel strength is mainly expressed in gel 0 and gel 10. The gelation measure at $10 \mathrm{~s}$ is called gel 0 while the gelation measure at $10 \mathrm{~min}$ is called Gel 10 . Figures 8 and 9 indicate that the gel strength of drilling mud was increased with increasing the concentration of the LLP as compared to the gel strength of reference mud. After hot rolling of mud samples (shown in Fig. 9), the Gel 0 and Gel 10 value of reference mud were 8 and 16, respectively. However, the gel 0 value of $1 \%, 2 \%, 3 \%, 4 \%$ and $5 \%$ LLPbased mud were $10,12,14,16$ and 18 , respectively. Similarly, the Gel 10 value of $1 \%, 2 \%, 3 \%, 4 \%$ and $5 \%$ LLP-based mud were $17,19,22,24,26$, respectively. The experimental results of Gel 0 and Gel 10 are showing fragile gelation not a progressive gelation. As per Ramsey (2019), Baker (2006) fragile gelation is very essential for optimum drilling operation means the difference between the Gel 0 and Gel 10 values should be less, because this gelation ensure that no excess share stress is required to break the gel again into the fluid when drilling operation would be resumed. Hence, due to good gelation property of LLP, it will help to hold the drill cuttings during the static condition. FTIR test shows the presence of hydroxyl $(-\mathrm{OH})$ group, indicating the reason of moderate effect of LLP on the viscosity and gelation of drilling fluid.

\section{Effect of litchi leaves powder (LLP) on the filtration properties of drilling fluid system}

The experiment is carried out at ambient room temperature and at 100 psi pressure through the Whatman filter paper 
that acts as a semi-permeable membrane. The samples of drilling fluid were hot rolled at $100{ }^{\circ} \mathrm{C}$ for $18 \mathrm{~h}$ and then the filtration loss was measured.

The filtration loss of different mud samples was measured at two conditions: before hot rolling (BHR) and after hot rolling (AHR). Figure 10 shows that before hot rolling, the filtration loss volume of reference mud was $27 \mathrm{ml}$ while after hot rolling at $100{ }^{\circ} \mathrm{C}$ for $18 \mathrm{~h}$ the filtration loss volume of same mud was increased to $32 \mathrm{ml}$. This observed result is due to decrease of edge to edge and edge to face attractive forces among the bentonite particles with temperature. Thus, to control filtration loss in drilling fluid, the external fluid loss agents such as LLP were used to introduce the crosslinking in the bentonite particles. The result as presented in Table 4 revealed that after hot rolling of mud samples at $100{ }^{\circ} \mathrm{C}$ for $18 \mathrm{~h}$, there was a reduction of about $70.6 \%$ (i.e. from 32 to $9.4 \mathrm{ml}$ ) in filtration loss volume at $5 \%$ concentration of LLP mud sample. This filtration loss reduction indicates that LLP introduced the cross-linked among the bentonite particles by strengthening the edge to edge and edge to face force of attraction between the particles. However, a comparison result of LLP and the standard polymers CMC (LVG) fluid loss volume are presented in Tables 4 and 5, respectively. Figure 11 shows that after hot rolling of mud samples at $100{ }^{\circ} \mathrm{C}$, the filtration loss of $1.4 \% \mathrm{CMC}$ was reduced by $67.5 \%$ (from 32 to $10.4 \mathrm{ml}$ ). These results indicate that 5\% LLP and bentonite particles formed an effective seal as compared to CMC (LVG) during the filtration loss. Therefore, the fluid loss control ability of 5\% LLP is more favourable than $1.4 \% \mathrm{CMC}$.

\section{Effect of LLP on the filter cake of Drilling Fluid}

\section{Filter cake thickness}

Experimental results showed that after hot rolling at $100{ }^{\circ} \mathrm{C}$, LLP significantly reduced the filter cake thickness as compared to base mud and the CMC (LVG) mud system. $4 \%$ and

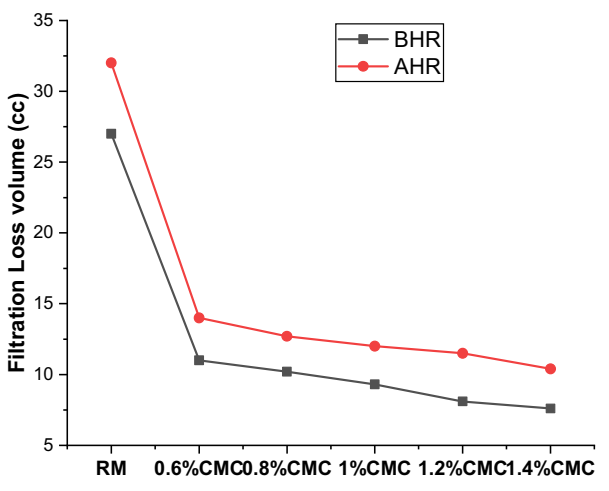

Fig. 11 Effect of CMC (LVG) on Filtration loss before and after hot rolling at $100{ }^{\circ} \mathrm{C}$

5\% LLP have reduced the filter cake thickness by $37.14 \%$ and $48.5 \%$, respectively (shown in Fig. 12), whereas $1.2 \%$ and $1.4 \%$ CMC (LVG) reduced the filter cake thickness by $34.28 \%$ and $40 \%$, respectively, as compared to base mud (shown in Fig. 13). Hence, it has been inferred that 5\% concentration of LLP significantly reduced the filter cake thickness, which is comparable to the optimized concentration $1.4 \%$ of CMC (LVG).

The FTIR spectrum of LLP shows various functional group like $-\mathrm{OH},-\mathrm{COOH}$ and $-\mathrm{NH}_{2}$ group. These functional group have a great tendency to form inter and intramolecular cross-link among the particles (Ermis et al.2018). The chemical cross-linking in the drilling fluid made filters cake impermeable, strengthful and thin, as a results the filtration loss was reduced significantly by the addition of LLP additive.

\section{Slickness and strength of the filter cake}

From the physical examination of filter paper (shown in Fig. 2c), it was seen that the filter cake formed by the $5 \%$ LLP was smooth, strengthening and slippery. These

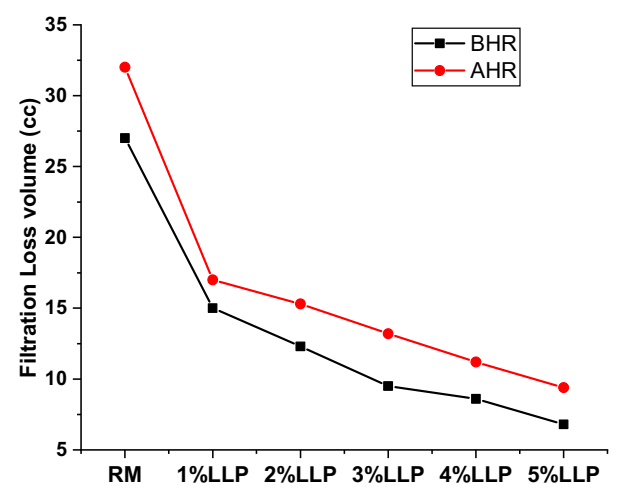

Fig. 10 Effect of LLP on the Filtration loss

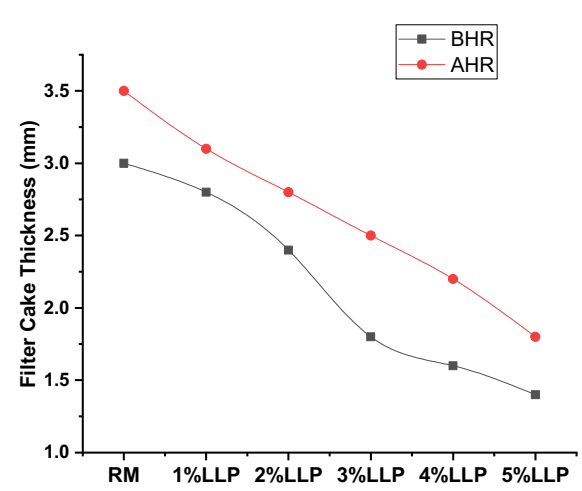

Fig. 12 Effect of LLP on the filter Cake Thickness (mm)

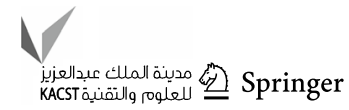




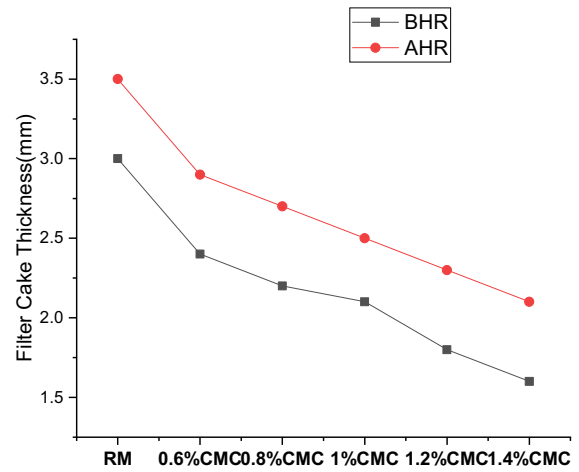

Fig. 13 Effect of CMC (LVG) on the Filter Cake Thickness (mm)

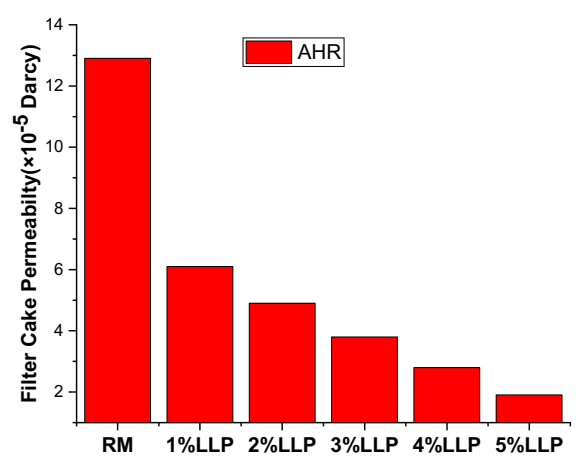

Fig. 14 Effect of LLP on the filter Cake Thickness permeability

characterizations of filter cake would help in the prevention of differential pipe sticking.

\section{Mud cake permeability}

The filter cake is formed on the permeable medium when the liquid part of the drilling fluid migrated through the medium under the influences of the pressure during drilling. The experimental data represented in Fig. 14 shows that after hot rolling of mud samples at $100{ }^{\circ} \mathrm{C}$, the permeability of the filter cake was reduced with increasing the concentration of LLP. The permeability of the filter cake formed by $4 \%$ and $5 \%$ LLP was $2.5 \times 10^{-5} \mathrm{D}$ and $1.9 \times 10^{-5} \mathrm{D}$, respectively. While the permeability of $1.4 \%$ $\mathrm{CMC}$ was $2.5 \times 10^{-5} \mathrm{D}$ (shown in Fig. 15) These data proved that the filter cake formed by $4-5 \%$ LLP mud have a greater plugging tendency to prevent the flow of filtrate from the filter cake as compared to $1.4 \%$ CMC. However, due to the higher permeability of the filter cake made by reference mud, i.e. $12.9 \times 10^{-5} \mathrm{D}$, indicates the greater filtration loss in reference mud (Table 6).

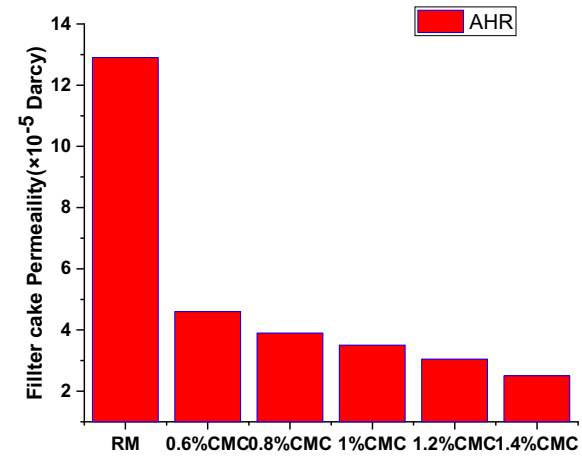

Fig. 15 Effect of CMC (LVG) on the Filter Cake Permeability

Table 6 Cake permeability for water-based mud formulated after hot rolling of mud samples at $100{ }^{\circ} \mathrm{C}$

\begin{tabular}{llll}
\hline Concentration & $\begin{array}{l}\text { Filter cake } \\
\text { permeability } \\
\text { (D) }\end{array}$ & Concentration & $\begin{array}{l}\text { Filter cake } \\
\text { permeability } \\
\text { (D) }\end{array}$ \\
\hline RM & $12.9 \times 10^{-5}$ & $\mathrm{RM}$ & $12.9 \times 10^{-5}$ \\
$1 \% \mathrm{LLP}$ & $6.08 \times 10^{-5}$ & $0.6 \% \mathrm{CMC}(\mathrm{LVG})$ & $4.6 \times 10^{-5}$ \\
$2 \% \mathrm{LLP}$ & $4.9 \times 10^{-5}$ & $0.8 \% \mathrm{CMC}(\mathrm{LVG})$ & $3.9 \times 10^{-5}$ \\
$3 \% \mathrm{LLP}$ & $3.8 \times 10^{-5}$ & $1 \% \mathrm{CMC}(\mathrm{LVG})$ & $3.5 \times 10^{-5}$ \\
$4 \% \mathrm{LLP}$ & $2.8 \times 10^{-5}$ & $1.2 \% \mathrm{CMC}(\mathrm{LVG})$ & $3.05 \times 10^{-5}$ \\
$5 \% \mathrm{LLP}$ & $1.9 \times 10^{-5}$ & $1.4 \% \mathrm{CMC}(\mathrm{LVG})$ & $2.5 \times 10^{-5}$ \\
\hline
\end{tabular}

\section{Conclusion}

The detailed experimental studies carried out on litchi leaves powder have ultimately qualified it as one of the best fluid loss green additive, a natural waste of litchi plant (Litchi chinensis), easily biodegradable. The study can be concluded by following few observations:

- LLP is a biodegradable, non-pollutant, cost effective, multifunctional, bio-enhancer and environmentally friendly additive.

- The thermal stability of the LLP as drilling fluid additives has been proven to withstand a range of temperature up to $100{ }^{\circ} \mathrm{C}$. This temperature resistant property make it more effective additive in the water-based drilling fluid.

- FTIR spectrum confirmed the different functional group such as hydroxyl (-OH) group, carbonyl group (aldehyde or ketone), carboxylic acid $(-\mathrm{COOH})$, amine group and halide group in the LLP.

- The samples of the LLP blended drilling fluid, hot rolled at $100{ }^{\circ} \mathrm{C}$, had negligible effect on the mud weight. There was no increase in the total solid content and hence specific gravity of resultant drilling fluid was almost constant. The foaming issue associated with the 
addition of this product was taken care of, by adding suitable de-foamers.

- The addition of LLP had little effect on plastic viscosity at $1-2 \%$ concentration. However, at higher concentration, above $2 \%$, plastic viscosity was found to be increased, although this enhancement was very less as compared to CMC Polymer, which make it better additive than CMC.

- Addition of the LLP had little effect on the yield point of drilling fluid at lower concentration (1-2\%), but at higher concentration (3-5\%) it increased YP as compared to reference mud.

- LLP significantly reduced the filter cake thickness of drilling fluid. After hot rolling at $10{ }^{\circ} \mathrm{C}, 4 \%$ and $5 \%$ LLP reduced filter cake thickness by $37.14 \%$ and $48.57 \%$, respectively, as compared to reference mud.

- LLP was found to be an effective water loss reducer and a befitting natural product that prevents hydration of very active clay and shale formation. It is a commercially viable alternative to other costly polymer like CMC, used for fluid loss reduction in the system. Results showed that after hot rolling at $100{ }^{\circ} \mathrm{C}$ for $18 \mathrm{~h}, 4-5 \%$ Litchi LLP reduced filtration loss by maximum $70.6 \%$. Its effect was compatible with $1.4 \%$ of $\mathrm{CMC}$ (LVG).

Hence, it has been concluded that the LLP is stable up to $100{ }^{\circ} \mathrm{C}$ like an existing fluid loss additive CMC (LVG). Therefore, $5 \%$ concentration of LLP can be used as a filtration loss control additive as an alternative to the optimized concentration of CMC (LVG) in water-based drilling fluid.

Acknowledgements Authors are thankful to IDT ONGC (Oil and Natural Gas Corporation Ltd.) Dehradun, Uttarakhand, India, for their kind support in the research.

Funding No known competing financial interests for this Manuscript.

\section{Declarations}

Conflict of interest On behalf of all authors, the corresponding author states that there is no conflict of interest.

Open Access This article is licensed under a Creative Commons Attribution 4.0 International License, which permits use, sharing, adaptation, distribution and reproduction in any medium or format, as long as you give appropriate credit to the original author(s) and the source, provide a link to the Creative Commons licence, and indicate if changes were made. The images or other third party material in this article are included in the article's Creative Commons licence, unless indicated otherwise in a credit line to the material. If material is not included in the article's Creative Commons licence and your intended use is not permitted by statutory regulation or exceeds the permitted use, you will need to obtain permission directly from the copyright holder. To view a copy of this licence, visit http://creativecommons.org/licenses/by/4.0/.

\section{References}

Adebowale A, Raji J (2015) Local content supplements as an alternative to imported corrosion control additives for drilling mud treatment (a case study of the use of burnt plantain and banana peels. In: Proceedings of the international academic conference for sub-Sahara African transformation and development, vol 3

Al-Hameedi ATT, Husam H (2019) Mandarin peels powder (MPP) as a filtration loss control additives to substitute the conventional chemicals used in water based drilling fluid in water based drilling fluid. J Pet Explor Prod Technol. https://doi.org/10.1007/ s13202-019-0725-7

Al-Hameedi ATT, Alkinani HH (2019) Environmental friendly drilling fluid additives: can food waste products be used as thinners and fluid loss control agents for drilling fluid? Soc Pet Eng. https:// doi.org/10.2118/195410-ms

Amanullah M (2007) Screening and evaluation of some environment friendly mud additives to use in water-based drilling muds. Society of Petroleum Engineers. E\&P Environmental and Safety Conference, 5-7 March, Galveston, Texas, USA, pp 1-9. https://doi. org/10.2118/98054-MS

Amanullah M, Tan CP (2001) Embedment modulus of mudcakes-It's drilling engineering significance. In: Paper AADE 01-NC-HO52 presented at the AADE 2001 National drilling conference, "Drilling Technology- the Next 100 Years" held at Houston, Texas

American Petroleum Institute. Third ed. (2003) Recommended Practice for Field Testing of Water Based Drilling Fluids (API 13B-1)

Ayurveda Formulary of India (2000) Ministry of health of family welfare. Govt of India

Baker H (2006) Drilling fluids reference manual. Baker Hughes Drilling Fluid, Houston

Chen C (2003) Evaluation of air oven moisture content determination methods for rough rice. Biosys Eng 86(4):447-457. https://doi. org/10.1016/j.biosystemseng.2003.08.010

Elkatatny S, Mahmoud MA, Nasr-El-Din HA (2012) Characterization of filter cake generated by water-based drilling fluids using CT scan. SPE Drill Complet 27(02):282-293

Ermis M, Calamak S, Kocal GC, Guven S, Durmus NG, Rizvi I, Demirci U (2018) Hydrogels as a new platform to recapitulate the tumor microenvironment. Handbook of Nanomaterials for Cancer Theranostics. Elsevier, Amsterdam, pp 463-494. https://doi.org/ 10.1016/B978-0-12-813339-2.00015-3

Engelhardt WV (1954) Filter cake formation and water losses in deep drilling muds. Circular No 191(6):191-194

Fomin S, Chugunov V, Hashida T (2003) Analytical modelling of the formation temperature stabilization during the borehole shut-in period. Geophys J Int 155(2):469-478

Ghazali NA, Mohd TAT, Alias NH, Azizi A, Harun AA (2014) The effect of lemongrass as lost circulation material (LCM) to the filtrate and filter cake formation. Key Eng Mater 594-595:68-72

Gray GR, Darley HCH, Rogers WF (1980) Composition and properties of oil well drilling fluids, 4th edn. Gulf Publishing, Houston

Iranwan S, Azmi A, Saaid M (2009) Corn cobs and sugar cane waste as viscosifier in drilling fluid. Pertanika J Sci Technol 17(173):181

Iheagwara $\mathrm{O}$ (2015) Comparative analysis of the Use of Banana Peels and $\mathrm{NaOH}$ in $\mathrm{pH}$ control in Nigerian clays. J Niger Assoc Math Phys 30:197-202

MI-Drilling fluids (2000) Drilling fluids manual

Nmegbu J, Bekee BA (2014) Evaluation of corn cob cellulose and its suitability for drilling mud formulation. J Eng Res Appl 4:112-117

Nyeche W, Nmegbu J, Ifeoma P (2015) Drilling mud formulation using potato starch (Ipomoea batatas). J Eng Res Appl 5:48-54

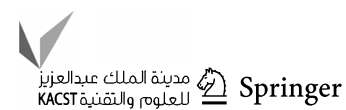


Okon AN, Udoh FD, Bassey PG (2014) Evaluation of rice husk as fluid loss control additive in water-based drilling mud. Soc Pet Eng. https://doi.org/10.2118/172379-ms

Agwu OE (2019) Rice husk and saw dust as filter loss control agents for water-based muds. Heliyon 5(7):e02059. https://doi.org/10. 1016/j.heliyon.2019.e02059

Okorie MO (2009) Modification of drilling fluid PH with local additives (ash of burnt palm head sponge [BPHSP] and a rich potash mineral known as Trona. Pet Technol Dev J 1:1-16

Okoro EE, Dosunmu A, Iyuke SE (2018) Data on cost analysis of drilling mud displacement during drilling operation. Data Brief 19:535-541. https://doi.org/10.1016/j.dib.2018.05.075

Omotioma M, Ejikeme PCN, Mbah GO (2014) Comparative analysis of the effects of cashew and mango extracts on the rheological properties of water based mud. J Eng Res Appl 4:56-61

Perlmutter BA (2005) Clean-in-place Operations for Thin-Cake Filtration Technologies. www.bhsfiltration.com/documents/Clarifying APISlurries.pdf. Accessed 14 June 2019

Prakash V, Sharma N, Bhattacharya M (2020) Feasibility studies of the environment-friendly Grewia optiva fibers as an alternative to the conventional noninvasive fluid additive (NIFA) in water-based drilling fluid. Pet Sci Technol 39:1-19. https://doi.org/10.1080/ 10916466.2020.1844230

Ramsey MS (2019) Rheology, viscosity, and fluid types. Pract Wellbore Hydraul Hole Clean. https://doi.org/10.1016/b978-0-12-817088-5. 00006-X

Shukla RK, Painuly D, Porval A, Shukla A (2014) Proximate analysis, nutritional value, phytochemical evaluation, and biological activity of litchi chinensis Sonn. Leaves J Herbs Spices Med Plants 20(2):196-208. https://doi.org/10.1080/10496475.2013.848830

Xie SX et al (2018) An electrochemical adsorption method for the reuse of waste water-based drilling fluids. Nat Gas Ind B. https:// doi.org/10.1016/j.ngib.2018.03.005

Publisher's Note Springer Nature remains neutral with regard to jurisdictional claims in published maps and institutional affiliations. 